\title{
Hepatitis B Viral Load (HBV-DNA) with Age and Sex Stratifications in Bangladeshi People
}

\author{
Moyen Uddin $\mathbf{P k}^{1^{*}}$, Rabby $\mathbf{A}^{2}$, Nahar Begum SMK ${ }^{3}$, Kabir $\mathbf{Y}^{2}$, Rahman $\mathbf{M}^{4}$ and Absar $\mathbf{N}^{4}$ \\ ${ }^{1}$ Department of Biochemistry, Primeasia University, Dhaka-1213, Bangladesh \\ ${ }^{2}$ Department of Biochemistry \& Molecular Biology, Dhaka University, Bangladesh \\ ${ }^{3}$ Department of pathology, Anwer Khan Modern Medical College \& Hospital Ltd., Bangladesh
}

${ }^{4}$ Department of Biochemistry \& Molecular Biology, Rajshahi University, Bangladesh

"Corresponding author: Moyen Uddin PK, Department of Biochemistry, Primeasia University, Dhaka-1213, Bangladesh, Tel: +88029822133; E-mail: moyen.uddinpk@primeasia.edu.bd

Rec Date: June 25, 2014, Acc date: June 29, 2014, Pub date: July 1, 2014

Copyright: (c) 2014 Moyen Uddin PK, et al. This is an open-access article distributed under the terms of the Creative Commons Attribution License, which permits unrestricted use, distribution, and reproduction in any medium, provided the original author and source are credited.

\begin{abstract}
Background: Hepatitis B virus surface antigen (HBsAg) is used for the detection of Hepatitis B virus (HBV) infection and to predict disease progression.

Objectives: The main objective of this study was to observe the pattern of HBV viral load levels among people in terms of age and sex distribution in Bangladesh.

Method: Blood specimen was collected from 585 objects with HBsAg Positive and assayed for the quantity of hepatitis $B$ virus using PCR based technique.

Results: It is found from the study that the mean viral load was 353,500,000 DNA copies/ml for 20-35 age group, $249,300,000$ DNA copies/ml for 35-50 age group and 104,800,000 DNA copies/ml for 50-65 age group. The median HBV viral loads for male and female were 58,494 and 103,287 DNA copies/ml, respectively.

Conclusion: High viral load was observed in the 21-35 and 36-50 age group while females are at most risk due to HBV infection as their viral load is higher compared to male.
\end{abstract}

Keywords: Viral load; HBV infection; HBV DNA; Bangladesh

\section{Introduction}

Hepatitis B virus (HBV) infection is considered as a serious public health concern worldwide since more than 350 million people are chronic carriers of HBV [1]. Persistent HBV infection is a risk factor for the development of Hepatocellular Carcinoma (HCC) [2]. According to Liver Foundation of Bangladesh incidence of Hepatitis-B infection in Bangladesh is about $4 \%-7 \%$ of total population. About $3.5 \%$ of pregnant mothers in Bangladesh are the carriers of the hepatitis B virus. Among them those are HBeAg positive (about 90\%) will transmit the virus to their offspring [3]. According to a study published in 1996, 36\% of the Hepatocellular carcinoma is associated with hepatitis B infection in Bangladesh [4]. Influence of age and sex on the development of $\mathrm{HBV}$ carrier state has been studied and a consistent relation was found [5].

Hepatitis B Virus surface Antigen (HBsAg) is an important marker for the detection of HBV infection and also it can be used to predict disease progression [6]. In Bangladesh although there is setup for quantitative detection of $\mathrm{HBV}$ viral load but these tests are quite expensive and rare [7]. It should be also consider that co-infections and super-infections with other hepatitis viruses (e.g. HCV) may also occur [8]. Therefore, person's disease history, age, sex, vaccination status and previous tests results should be considered to guide appropriate testing. The purpose of our study was to present the pattern of HBV viral load levels among people in terms of age and sex distribution in Bangladesh.

\section{Materials and Methods}

All samples were collected from six different metropolitan city of Bangladesh. Metropolitan cities have supply water system for drinking purpose and also sewage system parallel, most of the slum area have no proper sanitation system especially in the slum are of Dhaka city and hospitals do not have legitimate waste management system.

\section{Specimen collection and processing}

A bio-data was raised for each of the 585 subjects containing details of their age and sex. All subjects were informed about this study and only included if they permitted to use their data. Inclusion criteria for the subjects were age from 12 to 80 years old and HBsAg Positive. Only the first test carried out by a patient was included in this study. The specimen of choice for the diagnosis of HBV infection was blood. In brief, $5 \mathrm{ml}$ of blood was collected from each individual into EDTA treated tubes and centrifuged for 10 minutes. The plasma was separated and stored at $-20^{\circ} \mathrm{C}$ until analyzed. Patients had been previously confirmed as HBsAg positive and well aware about their inclusion in this study, prior to assessing the $\mathrm{HBV}$ viral load test. 
Citation: $\quad$ Moyen Uddin PK, Rabby A, Nahar Begum SMK, Kabir Y, Rahman M, et al. (2014) Hepatitis B Viral Load (HBV-DNA) with Age and Sex

\section{HBV DNA viral load assay}

Samples were assayed for the quantity of hepatitis B virus according to the SMART CYCLER HBV monitor test Version 2.0, a PCR based technique. The HBV viral load results were expressed in DNA copies/ml.

\section{Statistical analyses}

Graph Pad Prism 5 was used for statistical analysis and test of significance was done using Kruskal-Wall is statistical packages [9]. Differences of $\mathrm{p}<0.05$ were taken to be statistically significant at $95 \%$ confidence interval.

\section{Results}

In brief, HBV viral load is found minimum 256 and maximum $15,645,417,077$ DNA copies/ml among the participants sample. The mean value of the viral load is observed using statistical analysis 263,000,000 DNA copies/ml with 95\% Confidence Interval (CI) (lower mean: 157,100,000; upper mean: 368,900,000). Mean Value at $75 \%$ Percentile is calculated 6,169,000 DNA copies $/ \mathrm{ml}$.

\begin{tabular}{|l|l|l|l|l|l|}
\hline Values\Age Distribution (Years) & $\mathbf{2 0}$ & $\mathbf{2 0 - 3 5}$ & $\mathbf{3 6 - 5 0}$ & $\mathbf{5 1 - 6 5}$ & $\mathbf{7 6 5}$ \\
\hline Mean & $1,562,000$ & $273,800,000$ & $228,100,000$ & $104,000,000$ & 20,334 \\
\hline Median & 21,546 & 28,749 & 57,646 & 54,823 & 22,565 \\
\hline Lower 95\% Cl of mean & $-793,239$ & $120,400,000$ & $77,820,000$ & $-5,926,000$ & $-23,054$ \\
\hline Upper 95\% Cl of mean & $3,918,000$ & $427,200,000$ & $378,300,000$ & $214,000,000$ & 63,723 \\
\hline
\end{tabular}

Table 1: The age distribution of the HBV viral load

The participant's age range was from 20 to 65 Years. We have equally classified the age range into three categories: 20-35, 36-50 and 51-65 years of old (Table 1). As the life expectancy of Bangladeshi people is 69.8 years [10]; therefore this age distribution is covered the entire population of Bangladesh except younger population and children. The mean viral load found $353,500,000$ DNA copies $/ \mathrm{ml}$ for 20-35 age group, while it was $249,300,000$ DNA copies/ml for 35-50 age group and 104,800,000 DNA copies/ml for 50-65 age group. The median HBV viral loads for male and female were 58,494 and 103,287 DNA copies $/ \mathrm{ml}$, respectively $(\mathrm{P}>0.005)$ (Table 2$)$. Male to female ratio was 2:1.

\begin{tabular}{|l|l|l|}
\hline Values/Sex Distribution & Male & Female \\
\hline Mean & $218,800,000$ & $209,800,000$ \\
\hline Median & 36,627 & 36,548 \\
\hline Lower $95 \%$ Cl of mean & $113,300,000$ & $57,840,000$ \\
\hline Upper 95\% Cl of mean & $324,300,000$ & $361,700,000$ \\
\hline
\end{tabular}

Table 2: The sex distribution of the HBV viral load

\section{Discussion}

Infection with $\mathrm{HBV}$ is under control in developed countries, but it is still a serious public health problem in developing countries like Bangladesh. In this study we examined the viral load pattern of those assessing laboratory services at our site, being the only laboratory at present where HBV viral load is carried out commercially within the country. As such samples were received from a wide range of localities across the country. There was a wide age range observed by the patients, with the highest prevalence being between 30-39 years (Figure 1).

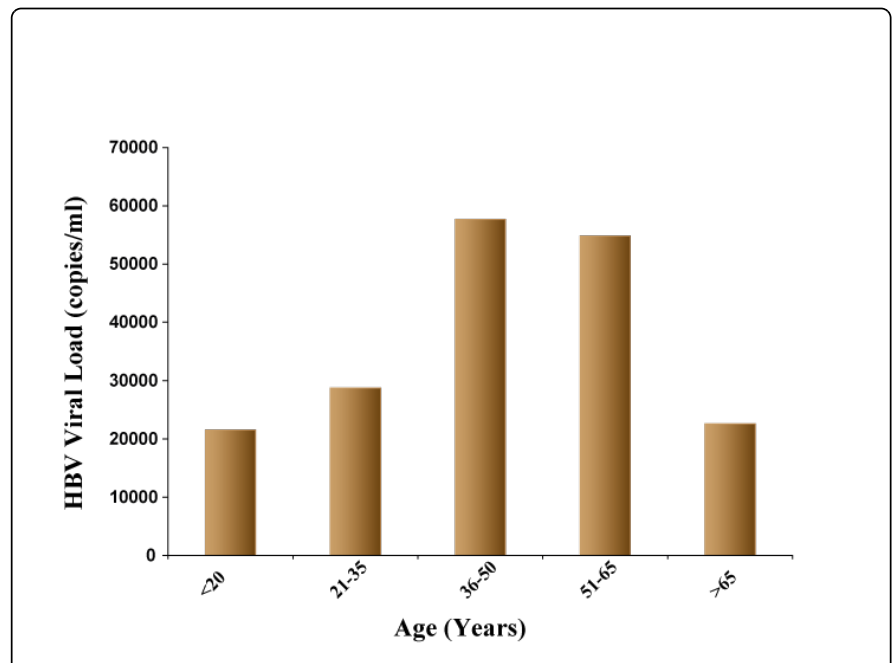

Figure 1: Prevalence of HBV viral load among different age group. Age group below 20 years has minimum viral load as people above 65 years old. On the contrary, People between 36 to 65 years old has highest risk of $\mathrm{HBV}$ infection.

Infection with $\mathrm{HBV}$ is a serious public health concern in Bangladesh like other developing countries. According to WHO [11], $2-5 \%$ of the general population in the Indian subcontinent is chronically infected with HBV. In this study viral load pattern was examined in the blood sample collected from various site of the country. In the wide age range of patients highest prevalence was observed between $36-50$ years (29.47\% of the population). Males have relatively higher prevalace than female. Country like Bangladesh males are the main work resourse; they travel to the different part of the country for business or job purpose, drink unhygienic resturant water or supply water from roadside small tea shop. Therefore males are 
Citation: $\quad$ Moyen Uddin PK, Rabby A, Nahar Begum SMK, Kabir Y, Rahman M, et al. (2014) Hepatitis B Viral Load (HBV-DNA) with Age and Sex Stratifications in Bangladeshi People. J Med Microb Diagn 3: 144. doi:10.4172/2161-0703.1000144

Page 3 of 3

likely to be exposed to the contamination rather than females. The lower and upper limit of viral load found in the analysis for the Hepatitis B monitor assay is $128,300,000$ and $301,900,000$ DNA copies/ $\mathrm{ml}$ respectively.

HBV viral load is important for clinical monitoring and treatment of individual with high HBV viral load as it is an indepenednt predictor of liver cancer lisk. Measurements of HBV viral load and genotype may help to define which male HBV carriers aged 30 years or older are at high risk for HCC [12]. our study showed that HBV is more prevalent in male group and in the 36-50 age group. According to a Taiwanises study the risk of HCC is closely associated with HBV. They also showed that HBV DNA levels were persistently elevated in patients at highest risk of liver cancer [13]. Another study in the Gambia, West Africa showed that High-level HBV DNA (>10,000 copies/ml) was strongly associated with both HCC and cirrhosis (17and 39-fold increased risk); even Lower level HBV viremia (20010,000 copies/ml) confer a significant risk of HCC [14]. Though Antiviral treatment is the only way to reduce morbidity and mortality from chronic HBV infection but The implementation of mass immunization programs, which have been recommended by the World Health Organization since 1991, have dramatically decreased the incidence of $\mathrm{HBV}$ infection among infants, children, and adolescents in many countries [15].

However regular/routine screening of the HBV can alter that morbidity rate in Bangladesh and also the risk could be minimized if the National programme on immunization (NPI) scheme for HBV vaccination is implemented.

\section{Conclusion}

In conclusion, high viral load observed in the 21-35 and 36-50 age group where risk of HCC is involved. There were no study performed to compare the HBV viral load of metropolitopn population with rural poulation. Also it would be nice if geographical distribusion can be shown by further study. However, it is recommended that there should be health education for public and health care providers and also screening and vaccination of all special risk groups. National vaccination program and mass awareness about HBV infection can reduce the risk of viral infection and other associated disease.

\section{Acknowledgements}

We are thankful to Anwer Khan Modern Medical College \& Hospital Ltd, Dhaka, Bangladesh for their providing opportunity of sample collection and help to carry out the research work.

\section{Conflict of Interest}

There is no conflict of interest

\section{References}

1. Organization WH (2010) Introduction of hepatitis B vaccine into childhood immunization services. Department of Vaccines and Biologists, World Health Organization: Geneva 8-9.

2. Sherman M (2009) Risk of hepatocellular carcinoma in hepatitis B and prevention through treatment. Cleve Clin J Med 76 Suppl 3: S6-S9.

3. Bangladesh Lfo (2013) Incidence of Hepatitis-B infection in Bangladesh.

4. Khan M and Ahmad N (1996) Seroepidemiology of HBV and HCV in Bangladesh. International Hepatology Communications 5: 27-29.

5. Okwuraiwe A (2011) Experience with Hepatitis B viral load testing in Nigeria. African Journal of Clinical and Experimental Microbiology 12: 101-105.

6. Kao JH (2008) Diagnosis of hepatitis B virus infection through serological and virological markers. Expert Rev Gastroenterol Hepatol 2: 553-562.

7. Hasan KN, Rumi MA, Hasanat MA, Azam MG, Ahmed S, et al. (2002) chronic carriers of hepatitis $B$ virus in Bangladesh: a comparative analysis of HBV-DNA, HBeAg/anti-HBe, and liver function tests. Southeast Asian J Trop Med Public Health 33: 110-117.

8. Sato S, Fujiyama S, Tanaka M, Yamasaki K, Kuramoto I, et al. (1994) Coinfection of hepatitis $\mathrm{C}$ virus in patients with chronic hepatitis B infection. J Hepatol 21: 159-166.

9. Kruskal-Wallis anova was performed using GraphPad Prism version 6.0 for Windows. GraphPad Software, San Diego California USA.

10. Population of Bangladesh.

11. Hepatitis B (2014) in Fact Sheet 204.

12. Yu MW, Yeh SH, Chen PJ, Liaw YF, Lin CL, et al. (2005) Hepatitis B virus genotype and DNA level and hepatocellular carcinoma: a prospective study in men. J Natl Cancer Inst 97: 265-272.

13. Yu MW, Chang HC, Chen PJ, Liu CJ, Liaw YF, et al. (2002) Increased risk for hepatitis B-related liver cirrhosis in relatives of patients with hepatocellular carcinoma in northern Taiwan. Int J Epidemiol 31: 1008-1015.

14. Mendy ME, Welzel T, Lesi OA, Hainaut P, Hall AJ, et al. (2010) Hepatitis $B$ viral load and risk for liver cirrhosis and hepatocellular carcinoma in The Gambia, West Africa. J Viral Hepat 17: 115-122.

15. WHO (2000) Hepatitis B. World Health Organization Fact Sheet 204. 